\title{
Neural integration of tissue and whole-animal regulation of digestive secretions
}

\author{
BY CLAUDE ROZÉ \\ INSERM U410, Faculté de Médecine X Bichat, 16 Rue H. Huchard, \\ 75870 Paris Cedex 18, France
}

\section{Intégration nerveuse de la régulation des sécrétions digestives au niveau tissulaire et chez l'animal entier}

\begin{abstract}
RÉSUMÉ
Les importants progrès réálisés récemment dans le domaine de la biologie cellulaire et moléculaire ont permis d'apporter de nombreuses données sur les récepteurs membranaires et les mécanismes intracellulaires de transduction du signal dans les cellules digestives à fonction sécrétoire. Toutefois, chez l'animal entier, comme chez l'homme normal, les régulations cellulaires dans les circonstances physiologiques doivent prendre en compte de multiples facteurs de l'environnement tissulaire, et en particulier les connections afférentes et efférentes du tube digestif avec le système nerveux central. L'innervation sensitive du tube digestif, bien que très majoritairement inconsciente, informe en permanence et de manière détaillée le cerveau et les centres nerveux périphériques sur l'état de la digestion. Les neurones sensitifs du tube digestif comportent de nombreux capteurs capables de donner des informations sur l'état chimique de la lumière intestinale $(\mathrm{pH}$, nutriments présents, etc.), ainsi que sur les évènements physiques en cours (tension, contractions, osmolarité, température, etc.). De plus, ces neurones sensitifs portent de nombreux récepteurs capables de détecter la présence dans le milieu extracellulaire de divers messagers endocrines, paracrines ou neurocrines, et ces messagers sont capables de moduler le message sensitif.

Après avoir résumé quelques aspects importants de l'innervation sensitive et motrice du tube digestif, cet article présente quelques exemples montrant qu'in vivo, des peptides régulateurs endocrines ou paracrines agissent souvent de manière indirecte sur l'effecteur qu'ils contrôlent, par l'intermédiaire de la modulation de boucles nerveuses sensorimotrices. Les récepteurs portés par les neurones semblent alors mis en jeu à des concentrations plus faibles que les récepteurs des cellules sécrétantes effectrices ellesmêmes. Bien que plus compliqué, ce système de régulation indirecte permet probablement à l'organisme d'exercer une régulation plus fine des processus sécrétoires, grâce aux excellentes propriétés d'intégration du système nerveux, qui peut prendre en compte à chaque instant l'ensemble des informations dont il dispose concernant l'état de l'organisme.
\end{abstract}

Much progress has come in recent years from the study of in vitro systems. Receptors for various neuropeptides, and intracellular pathways used by extracellular messengers to trigger secretory changes in digestive tract epithelial cells have been successfully described in isolated normal cells (parietal cells, pancreatic acinar cells, enterocytes, etc.) and in cultured cell lines. A detailed study of the properties of various ion channels 
using patch clamp experiments provided insights into the mechanisms of ion transport in digestive epithelia. Molecular biological methods have allowed various molecules such as mammalian peptide receptors to be expressed in cell lines in which they were not previously present, such as the Chinese hamster ovary cell line. Studying the sequence of complementary DNA (cDNA) has allowed precise definition of how many different molecules are required for complete receptor function, etc.

While this constitutes very precious information about the way that life has managed to reach the splendid organization of a mammalian cell, all these methods are insufficient to describe the normal function of an organ in its physiological environment in vivo. This is due to the complex interplay of endocrine and neural pathways sending messages to the target cell. These messages depend to a great extent on the cabled network of neurons which can change to a surprisingly great extent the mechanism of action of extracellular messengers. Thus, some endocrine molecules will not act directly on their target cells, but rather through the activation of sensory neurons and neural reflex pathways. Conversely, mucosal open-type endocrine cells, although directly sensitive to elemental nutrients in the gut lumen, may rather be physiologically activated through neural pathways.

The purpose of the present paper is first to review some comparatively recent data on the general organization of digestive tract innervation, and to then show some examples of indirect in vivo regulation of effector cells through the activation of neural pathways.

\section{GENERAL ORGANIZATION OF DIGESTIVE TRACT INNERVATION}

The gut is both the largest endocrine organ in the body and an important neural centre: it is currently estimated that it contains as many intrinsic neurons as the whole spinal cord. Intrinsic neurons (the 'gut brain') are organized as plexuses (submucosal or Meissner's, and myenteric or Auerbach's). Although they can process some programmed functions, they are physiologically controlled by extrinsic centres.

\section{Motor pathways}

Autonomic extrinsic motor pathways to the gut have been known for a long time to comprise at least two neurons. The cell body of the first vagal motor neuron (protoneuron) lies in the dorsal motor nucleus of the vagus (DMNV), in the medulla, while sympathetic protoneurons reside in the anterior horn of the spinal cord. Both parasympathetic and sympathetic protoneurons synapse in ganglia through cholinergic nicotinic junctions with a second-order motor neuron. Parasympathetic ganglia lie within the organs while sympathetic ganglia which supply innervation to the gut are prevertebral. During the last 20 years, some information has gradually emerged which differs from the classical conception of the motor autonomic system. Vagal efferent fibres have been shown to be limited to comparatively small numbers $(10-20 \%$ of total fibres in the abdominal vagus), and to synapse within the myenteric plexus with both excitatory and inhibitory second-order neurons (at least as far as motility is concerned). Acetylcholine remains the main excitatory motor transmitter through muscarinic receptors, while several candidates for the function of inhibitory non-cholinergic non-adrenergic transmitters (NANC) have appeared, the most popular currently being NO and vasoactive intestinal peptide (VIP). 
Newer aspects of sympathetic transmission in the digestive system concerned mainly the function of prevertebral ganglia and the site of termination of noradrenergic fibres. Noradrenergic motor neurons, whose cell body is located in the prevertebral ganglia, appear to function as important integration sites: in addition to the preganglionic motor terminals, they also receive synaptic input from many sensory fibres conveying information from the gut (mainly from mechanoreceptors). Prevertebral ganglia can thus function as integrative and reflex centres, especially for the colon and rectum. The site of termination of motor noradrenergic fibres resides on vascular smooth-muscle cells as far as intestinal circulation is concerned. However, in the gut-wall muscle, noradrenergic fibres make few contacts with smooth-muscle cells, but rather impinge in a presynaptic fashion upon intrinsic excitatory motor fibres, to reduce acetylcholine and other excitatory neurotransmitter release from these neurons, which are themselves tonically activated by vagal or pelvic parasympathetic fibres (at least in non-sphincteric regions of the gut).

\section{Sensory innervation}

Although earlier studies provided some information, it was during the 1980 s that it was fully realized that sensory innervation of the digestive tract was much more extensive than had been thought before. The abdominal vagus nerve thus appeared as a primarily sensory nerve, containing $80-90 \%$ of sensory fibres, whereas a whole variety of mucosal, muscular and serosal receptors was described in the gut (for review, see Mei, 1983).

Methods of testing the organization and function of sensory neurons. Mapping extrinsic sensory neurons takes advantage of several methods. Degeneration studies are the oldest that have been used: following nerve section, the part of the axon which is distal to the section with respect to the nerve cell body will degenerate in a few days or weeks. Knowing the location of cell bodies (for example, in the nodose ganglion for vagal sensory fibres) and counting the remaining axons some days after section thus allows sensory fibres to be distinguished from motor fibres. It is necessary to count the fibres under the electron microscope, because most sensory fibres from the gastrointestinal tract are small diameter, unmyelinated fibres, which could not be counted in the early studies which relied on optical microscopy.

Precise description of the projection pattern of nerve fibres takes advantage of the properties of axonal flow, which transports various molecules from the cell body to the nerve terminals (anterograde transport) and also from nerve terminals to the cell body (retrograde flow). Several markers have been used for this purpose: the most common is horseradish peroxidase ( $E C$ 1.11.1.7; HRP) which was first used as a retrograde marker, but was later shown also to be transported in the anterograde direction (Mesulam, 1982). To increase sensitivity and limit tracer spread from the injection site, HRP has been linked to other molecules such as lectins (wheat-germ agglutinin) or cholera toxin; this has the advantage that the entire dendritic tree of a retrogradely-labelled neuron is filled with the tracer (Wan et al. 1982). Fluorescent dyes, such as true blue or fluorogold, have also proved useful for anatomical studies (Taylor et al. 1983). These methods can be efficiently coupled with the immunochemical detection of neuropeptides, thus allowing neurons containing, for instance, calcitonin-gene-related peptide (CGRP) or substance $P$, two of the most-widely-distributed sensory neuropeptides to be traced.

More recently, a functional approach has made it possible to map the neurons 
activated following some discrete event, by using fos protein, a nuclear phosphoprotein controlled by the immediate-early gene c-fos. The immunochemical detection of fos-like immunoreactivity can be used as a specific and reproducible marker to map functional excitatory pathways in the central nervous system. Expression of c-fos is rapidly and transiently induced in brain neurons that are trans-synaptically activated by a wide range of somato-cutaneous or visceral sensory stimuli (Menetrey et al. 1989). Peptides involved in neural regulation of gastrointestinal function, such as cholecystokinin (CCK; Fraser \& Davison, 1992), bombesin (Bonaz et al. 1993b) and peptide YY (Bonaz et al. 1993a) induce c-fos immunoreactivity in various brain areas, and especially in the nucleus tractus solitarius (NTS), where vagal primary sensory fibres synapse. In the central nervous system, the advantage of immunochemical detection is that it allows identification of the complete series of neurons which are successively activated by the stimulus under study.

The neurotoxin capsaicin (8-methyl-N-vanillyl-6-nonenamide, a pungent constituent of chilli peppers) is also an important tool for studying the function of digestive sensory fibres. Capsaicin acts through specific receptors on a subpopulation of thin, unmyelinated, low-conduction-velocity fibres with sensory function, both in the somatic and visceral areas. Acute application of small doses of capsaicin to sensory fibres mimics their excitation by a sensory stimulus, while pretreatment by large doses of capsaicin, either systemically in neonate or adult rats, or locally to a nerve such as the vagus nerve, produces permanent or temporary degeneration of sensory fibres (Holzer, 1991). This results in true sensory denervation, permitting elucidation of mechanisms; for example, whether the effects of different substances are mediated by afferent nerves as part of an indirect mechanism of action.

Extrinsic sensory pathways. Extensive analysis of intestinal sensory receptors providing information to sensory extrinsic fibres has been performed by several groups. Since sensory endings generally have no specialized structure, but consist of free, thin, unmyelinated nerve endings issuing from the Schwann sheath, for instance in the gut mucosa, most data have come from functional studies obtained by recording neural activity with electrodes placed on afferent fibres or in the vicinity of the cell bodies of the $\mathrm{T}$-shaped sensory neurons in sensory ganglia. Two main groups of extrinsic sensory fibres were thus studied: vagal and spinal sensory neurons. The cell bodies of vagal primary sensory neurons (sensory protoneurons) are located in the nodose ganglion, and the central ends of these neurons project to the NTS. The cell bodies of splanchnic primary sensory neurons are located in dorsal root ganglia and their central terminal projects to the dorsal horn of the medulla to connect with spino-thalamic neurons that cross the midline and ascend in the anterolateral quadrant of the spinal cord to the thalamus. Some splanchnic neurons, however, also project to the NTS (Menetrey \& Basbaum, 1987) and may even affect directly the function of DMNV neurons (Renehan et al. 1995).

In contrast to the motor pathways, no systematic functional difference can be discerned between sympathetic and parasympathetic sensory neurons since both of them convey information from chemoreceptors and mechanoreceptors of various types (for review, see Mei, 1983). In addition, primary sensory neurons frequently send collaterals to both intrinsic neurons in the myenteric plexus and to prevertebral ganglia, which provide the basis for short reflexes in the gut.

Most sensory information from the gut is unconscious in physiological situations. Only in pathological cases does sensation occur which may manifest as visceral pain. The 
problem of pain is not yet clearly settled. It is generally admitted that pain from the gut is conveyed through splanchnic fibres. There may be some true nociceptors (high-threshold mechanoreceptors, or silent receptors) that become activated only in pathological conditions (for instance, in the case of inflammation), or alternatively, supramaximal stimulation of normally-unconscious receptors might give rise to pain by recruitment of many neurons (for review, see Sengupta \& Gebhart, 1994).

Intrinsic sensory neurons. Intrinsic sensory neurons are still poorly defined. Evidence for their presence is clear from functional studies, since several mucosal stimuli (chemical, mechanical) are able to activate peristaltic reflex waves in isolated gut segments. Their detection using microelectrodes shows them to be intraparietal cell bodies which do not receive synaptic input. Some of them, situated in the submucosal plexus, project to the myenteric plexus; others project to prevertebral ganglia.

Very localized mechanical stimuli administered to the small intestinal mucosa in vitro, with a 'picosprizter' injecting microbubbles of gaseous $\mathrm{N}_{2}$ from a micropipette, induces fos protein expression in the nuclei of submucosal and myenteric neurons (Kirchgessner et al. 1992; Gershon et al. 1994). Induction of c-fos is blocked by tetrodotoxin, indicating that axonal conduction is needed for the phenomenon to appear. Most of these neurons are activated through synaptic pathways, since 1,6-bis(trimethylammonium)-hexane ion (hexamethonium) does not prevent $\mathrm{c}$-fos induction in some submucosal neurons, but blocks its spread to myenteric neurons. This indicates that the submucosal neurons which express c-fos under stimulation are probably sensory neurons.

Motor function of sensory fibres. Sensory endings in the gut were first viewed as a receptive afferent system whose function was limited to elaborate centripetal influxes. This concept was questioned when it was found that antidromic stimulation of the peripheral stump of transected dorsal roots or sensory nerves induced vasodilation and other signs of inflammation in the skin. In the last 20 years, evidence has accumulated that sensory neurons may not only have a sensory role, but also take part in local effector systems regulating blood flow, vascular permeability, trophic and immunological processes, and smooth-muscle contractility (Holzer, 1988). This probably occurs through the common innervation of several peripheral structures by branches of the same sensory neuron. This particular branching pattern allows the local release of transmitters such as CGRP, substance $P$ and other peptides by one branch of the neuron, following activation of the sensory ending of another branch ('axon reflex'). In addition, transmitters are probably released also by the sensory branch itself following activation, since in experimental conditions local neurotransmitter release may still occur after blocking axonal conduction by tetrodotoxin. It should be emphasized also that many sensory endings possess receptors for various neurotransmitters and endogenous substances, and can be chemically excited by substances arising from neighbouring cells or nerves (acetylcholine, bradykinin, substance $\mathrm{P}$, serotonin, CCK, etc.).

Whatever the exact mechanism involved in normal and pathological sensory transmission, the presence of numerous sensory neurons bearing many receptors for chemical messengers is a fundamental dimension of integration in the digestive system: neurocrine, paracrine or endocrine molecules present in the immediate vicinity of sensory neurons can activate reflex loops which will stimulate or inhibit secretory and motor pathways to the stomach, intestine and pancreas. 


\section{INDIRECT CONTROL OF DIGESTIVE SECRETIONS THROUGH THE AUTONOMOUS NERVOUS SYSTEM}

Circulating regulatory peptides may act directly on their target cells. Secretin, for example, seems to interact directly with pancreatic duct cell receptors to induce water and bicarbonate secretion through a mechanism involving intracellular cAMP formation and opening of apical chloride channels.

In a number of cases, however, physiological events are different, and the regulatory peptide may rather act on neuronal receptors to activate (or inhibit) a neural response. This seems, for instance, to be the case when physiological doses of CCK act on pancreatic secretion.

\section{Cholecystokinin and pancreatic secretion}

It has been firmly established that pancreatic acinar cells possess $\mathrm{CCK}$ receptors. In the guinea-pig and in the rat these receptors are mainly of the $\mathrm{CCK}_{\mathrm{A}}$ subtype, although a minor proportion of $\mathrm{CCK}_{\mathrm{B}}$ and other $\mathrm{CCK}$ and gastrin receptors may occur. In pancreatic acini in vitro, CCK activates enzyme secretion in a dose-related fashion, by a pathway involving phospholipase $\mathrm{C}$ (EC 3.1.4.3), inositol triphosphate, $\mathrm{Ca}^{++}$and calmodulin-dependent protein kinase, diacylglycerol and protein kinase $\mathrm{C}$. These in vitro events are similar to the events produced by cholinergic activation of acinar-cell muscarinic receptors, but they are independent of the short range of muscarinic receptor blockade.

However, the in vivo situation is different. When small intravenous doses of CCK8 are infused into the rat, in order to produce circulating CCK levels approaching the levels obtained after a casein meal, CCK8-stimulated pancreatic secretion is suppressed by $\mathrm{CCK}_{\mathrm{A}}$ antagonists, but its mechanism clearly involves nerves: it is also blocked by atropine, by vagotomy, by tetrodotoxin, and by a preliminary treatment with perivagal capsaicin (Li \& Owyang, 1993). Taken together, these findings are consistent with a scheme in which CCK8 would interact with $\mathrm{CCK}_{\mathrm{A}}$ receptors situated peripherally on the axons of extrinsic vagal sensory neurons. Activation of these sensory neurons would in turn project to the NTS and activate a vagal reflex producing a cholinergic pancreatic stimulation. Complementary experiments suggest that endogenous $\mathrm{CCK}$ released by a duodenal casein meal in rats also stimulates pancreatic secretion via vagal afferents ( $\mathrm{Li} \&$ Owyang, 1994).

The situation in man cannot be analysed with such precision, since most drugs and neurotoxins used in the rat cannot be administered in adequate dosages to human subjects. However, it appears that the pancreatic response in healthy volunteers to small doses of caerulein is blocked by both atropine and by the $\mathrm{CCK}_{\mathrm{A}}$ antagonist, lorglumide, whereas the pancreatic response to intraduodenal test meals $(0.42$ or $1.26 \mathrm{MJ})$ is totally blocked by atropine, and only reduced by loxiglumide (Adler et al. 1991). Cholinergic stimulation might thus be the main factor modulating normal pancreatic secretion in man. By analogy with the rat situation, it is postulated that CCK acts through an afferent pathway to reinforce the cholinergic output to the pancreas. However, this role of afferent fibres has not been demonstrated in man.

Apart from the pancreas, modulation of vagal function by $\mathrm{CCK}_{\mathrm{A}}$ receptors located on sensory fibres has been abundantly demonstrated for gastric motor function in the rat. 
CCK decreases proximal gastric motility, relaxes the fundus, but enhances antral and pyloric contractions. Perivagal application of capsaicin strongly reduces CCK-induced proximal gastric relaxation and completely abolishes the CCK-induced delay in emptying of a non-nutrient meal in the rat (Raybould \& Taché, 1988). Receptors for CCK $\left(\mathrm{CCK}_{\mathrm{A}}\right)$ and many other peptides (opiates, angiotensin II, neurotensin, peptide YY) have been demonstrated in the vagus nerve, and their transport has been studied (Moran \& $\mathrm{McHugh}, 1992$ ). Usually anterograde transport is easily identified, while retrograde transport is less evident. This may be due to the state of the receptor during retrograde transport (ligand-associated?) or to inadequate techniques.

\section{Modulation of vagovagal reflexes}

From a general point of view, many interactions affecting the digestive tract take place through the modulation of vagovagal reflexes by neural and endoneurocrine factors (for review, see Rogers et al. 1995). Gastrointestinal vagal afferents probably terminate on both cell bodies and distal dendrites of NTS neurons. A subset of NTS neurons then closes the reflex loop by terminating on cell bodies within the DMNV. Some of these NTS second-order neurons ramify extensively through the DMNV and actually form large glove-like endings on the visceral efferent neuron cell bodies. The main neurotransmitters associated with the NTS to DMNV projections (enkephalins, catecholamines and $\gamma$-aminobutyric acid) all have inhibitory actions on gastrointestinal functions mediated by the DMNV. Biocytin and peroxidase morphology studies provided information on the NTS interneurons that receive vagal afferent input and in turn control vagal efferent output (Rogers \& McCann, 1993). Neurons in this region possess very long and spectacular dendritic arborizations passing through the termination zones of all the vagal afferent inputs from the digestive tract. They may be exposed, therefore, to a wide variety of vagal afferent signals. Some of these NTS neurons also possess dendritic processes that extend into the extreme medial NTS and the area postrema, a zone which does not possess a vascular diffusion barrier (Gross et al. 1990). These neurons may thus be exposed to circulating humoral signals as well; for instance, circulating labelled PYY has been shown to bind to receptors of the dorsal vagal complex (Hernandez et al. 1994).

Although most NTS to DMNV reflexes appear to inhibit vagal cholinergic peripheral output or to stimulate vagal NANC efferent second-order fibres, some positive modulations occur, such as pancreatic stimulation via CCK. Descending control, also, is exerted over the dorsal vagal complex. An extensive innervation of the DMNV and NTS has been shown to come from the nuclei of raphe obscurus, a midline medullary structure which contains copious amounts of thyrotropin-releasing hormone (TRH) and serotonin (5-hydroxytryptamine; 5-HT). A substantial concentration of receptors for both 5-HT and TRH are located on NTS and DMNV neurons (Rogers \& Hermann, 1992). It has been known for a long time that picomolar amounts of TRH applied to cerebral ventricles or to the dorsal vagal complex evoked large increases of gastric secretion, motility and transit via vagal activation. 5-HT, although weakly active in itself, powerfully synergizes TRH effects on gastric functions through 5-HT2 receptors (Yoneda \& Taché, 1995). These findings show again that a powerful central control is exerted by central neuropeptides upon digestive secretions, and that peripheral signals may modulate this central control through the high permeability zone of the area postrema. 


\section{PEPTIDE YY (PYY) RELEASE}

Having illustrated the indirect neural effects of circulating regulatory peptides, I should like to shortly describe an example of the converse, i.e. neural participation to the release of a regulatory peptide from endocrine cells of the gut.

PYY is a thirty-six amino acid endocrine peptide synthesized mainly in the open-type endocrine L-cells of the distal intestine mucosa. L-cells are absent from the proximal intestine; they begin to appear in the distal half of the small intestine, and are abundant in the distal ileum, caecum, colon and rectum in all mammalian species studied, including man. Apart from the PYY precursor, L-cells also synthesize proglucagon, and this molecule is processed in L-cells in a different way from that occurring in pancreatic glucagon A-cells. Although PYY-containing cells are not found in the proximal small intestine, it has been shown in the dog that the contact of nutrients with the proximal small intestine mucosa is able to trigger PYY release from the distal intestine, through several mechanisms involving especially CCK and the vagus nerve (Greeley et al. 1988). To test the general relevance of this phenomenon, we studied the mechanisms of PYY release in the rat.

In these experiments, PYY release was triggered in anaesthetized rats by the intraduodenal administration of a semi-liquid meal of $3 \mathrm{ml}$, containing $21 \mathrm{~kJ}$, which represents about one-tenth of the daily energy intake of a normal rat. Energy was provided as (\%) 57 carbohydrate, 13 lipid, 30 protein (Fu-Cheng et al. 1995a). Intraduodenal administration of this meal produced in control rats a copious release of PYY which changed from a fasting level of about $30 \mathrm{pg} / \mathrm{ml}$ to a peak of about $400 \mathrm{pg} / \mathrm{ml}$ after $1 \mathrm{~h}$. At $2 \mathrm{~h}$ after meal administration, plasma PYY had returned to about $200 \mathrm{pg} / \mathrm{ml}$. However, when intestinal transit of the intraduodenal meal was followed with a marker, it appeared that by $120 \mathrm{~min}$, the front of the meal had moved through $75 \%$ of the total small intestinal length, thus it was just beginning to reach the L-cell-rich ileal zone, and was without any possible contact with the L-cell-rich caecum and colon. Moreover, acute caeco-colectomy decreased PYY release by about $70 \%$, indicating that most of the released PYY came from the caecum and colon. It thus appeared that an indirect mechanism, originating in the duodenum or proximal jejunum was responsible for PYY release from the distal gut in the rat as well as in the dog. Complementary studies showed differences from, as well as similarities to the dog situation. CCK, bombesin, and muscarinic receptors did not seem to participate in the PYY response to meal, although supraphysiological doses of exogenous CCK and bombesin were able to release some PYY (Fu-Cheng et al. 1995b). Nerves and nicotinic synapses were involved, since vagotomy, tetrodotoxin, hexamethonium, and perivagal capsaicin application decreased the meal-induced PYY release by $60-80 \%$. In addition, the NO-synthase inhibitor, L-N-arginine methyl ester, reduced the meal-induced PYY release by $60 \%$, suggesting that NO release was involved in L-cell stimulation.

Taken together, these findings indicate that the in vivo activation of an endocrine mucosal cell releasing a gastrointestinal regulatory peptide is more dependent on neural control than might have been suspected from in vitro experiments. Although nutrients are able to directly release PYY and proglucagon-derived peptides from cultured L-cells, as well as from isolated perfused rat colon, most of the meal-induced physiological PYY release occurs in vivo through neural mechanisms which do not involve the direct contact of nutrients with colonic L-cells. 


\section{NEURO-IMMUNE CONTROL OF WATER AND ELECTROLYTE SECRETION IN THE SMALL INTESTINE}

The small intestinal epithelium is richly innervated by a large variety of intrinsic neurons containing diverse neurotransmitters and peptides. Some of them, as emphasized earlier (p. 311), represent sensory neurons, although their morphological identification as sensory or motor is at present impossible. Besides the various types of epithelial cells (enterocytes, goblet cells, M-cells, Paneth cells), intestinal epithelium contains intraepithelial lymphocytes, and the lamina propria contains $\mathrm{T}$ and $\mathrm{B}$ lymphocytes, plasma cells, macrophages, mast cells, eosinophils and neutrophils. Antigenic stimulation results in expansion of the resident immune cell population, both in the lamina propria and sometimes within the epithelium. Immune stimulation may also result in release of various cytokines, enzymes, oxidants and neurotransmitters, many of which affect epithelial functions.

Morphological studies have demonstrated that mucosal mast cells form intimate associations with nerves (Stead et al. 1987). Such anatomic relations have also been reported for other immune cells. Many aspects of epithelial physiology, and primarily epithelial ion secretion, may be regulated by immune-neural factors. In vitro Ussing chamber experiments have shown that specific immune stimulation initiated a rapid secretory response involving increased net $\mathrm{Cl}^{-}$secretion through the release of histamine and other mast cell mediators. Although only substance $\mathrm{P}$ appeared able to elicit histamine release from rat intestinal mucosal mast cells, neural blockers or receptor antagonists such as hexamethonium, lidocaine, atropine, and capsaicin pretreatment were able to inhibit antigen-induced secretory responses, indicating that the immune cells' mediators interfere with nerves to elicit secretion (for review, see Perdue \& McKay, 1994). Among them, histamine and 5-HT induce secretion by acting on receptors of enteric nerves. The secretion induced by cholera toxin is inhibited by blocking 5-HTlp and 5-HT3 receptors. Finally, intestinal secretory responses to Clostridium difficile toxin A associated with mast cell activation are inhibited by a variety of neural antagonists, including lidocaine and capsaicin (Castagliuolo et al. 1994), as well as by substance $\mathrm{P}$ antagonists (Pothoulakis et al. 1994).

In conclusion, the examples presented in the present paper show that in many cases, the in vivo mechanisms of action of extracellular messengers are not direct on the secretory effector cells of the digestive tract. They rather involve the indirect activation of neural reflexes involving the enteric and central nervous systems. In these mechanisms, sensory neurons predominate, both by the numerous messages they send to inform the centres, and through the local release of neuropeptides and other substances able to interact with immune, endocrine and epithelial cells of the gut.

\section{REFERENCES}

Adler, G., Beglinger, C., Braun, U., Reinshagen, M., Koop, I., Schafmayer, A., Rovati, L. \& Arnold, R. (1991). Interaction of the cholinergic system and cholecystokinin in the regulation of endogenous and exogenous stimulation of pancreatic secretion in humans. Gastroenterology 100, 537-543.

Bonaz, B., De Giorgio, R. \& Taché, Y. (1993a). Peripheral bombesin induces c-fos protein in the rat brain. Brain Research 600, 353-357.

Bonaz, B., Taylor, I. \& Taché, Y. (1993b). Peripheral peptide YY induces c-fos-like immunoreactivity in the rat brain. Neuroscience Letters $163,77-80$. 
Castagliuolo, I., La Mont, J. T., Letourneau, R., Kelly, C., O'Keane, J. C., Jaffer, A., Theoarides, T. C. \& Pothoulakis, C. (1994). Neuronal involvement in the intestinal effects of Clostridium difficile toxin A and Vibrio cholerae enterotoxin in rat ileum. Gastroenterology 107, 657-665.

Fraser, K. A. \& Davison, J. S. (1992). Cholecystokinin-induced c-fos expression in the rat brain stem is influenced by vagal nerve integrity. Experimental Physiology 77, 225-228.

Fu-Cheng, X., Anini, Y., Chariot, J., Voisin, T., Galmiche, J. P. \& Rozé, C. (1995a). Peptide YY release after intraduodenal, intraileal, and intracolonic administration of nutrients in rats. European Journal of Physiology 431, 66-75.

Fu-Cheng, X., Chariot, J., Martinez, J. \& Rozé, C. (1995b). Rôle du nerf vague, de la cholécystokinine et de la bombésine dans les mécanismes nerveux de la libération post-prandiale de peptide YY chez le rat (Role of the vagus nerve, cholecystokinin and bombesin in the neural control of post-prandial PYY release in the rat). Gastroentérologie Clinique et Biologique 19, 416 Abstr.

Gershon, M. D., Kirchgessner, A. L. \& Wade, P. R. (1994). Functional anatomy of the enteric nervous system. In Physiology of the Gastrointestinal Tract, 3rd ed., pp. 381-422 [L. R. Johnson, D. H. Alpers, J. Christensen, E. D. Jacobson and J. H. Walsh, editors]. New York: Raven Press.

Greeley, G. H., Jeng, Y. J., Gomez, G., Hashimoto, T., Hill, F. L. C., Kern, K., Kurosky, T., Chuo, H. F. \& Thompson, J. C. (1988). Evidence for regulation of peptide YY release by the proximal gut. Endocrinology 124, 1438-1443.

Gross, P. M., Wall, K. M., Pang, J. J., Shaver, S. W. \& Wainman, D. S. (1990). Microvascular specializations promoting rapid interstitial solute dispersion in nucleus tractus solitarius. American Journal of Physiology 259, R1131-R1138.

Hernandez, D. E., Arredondo, M. E., Xue, B. G. \& Jennes, L. (1994). Saturable binding of circulating peptide YY in the dorsal vagal complex of rats. American Journal of Physiology 266, G511-G516.

Holzer, P. (1988). Local effector functions of capsaicin-sensitive sensory nerve endings: involvement of tachykinins, calcitonin-related peptide and other neuropeptides. Neuroscience 24, 739-768.

Holzer, P. (1991). Capsaicin: cellular targets, mechanisms of action, and selectivity for thin sensory neurons. Pharmacological Reviews 43, 143-201.

Kirchgessner, A. L., Tamir, H. \& Gershon, M. D. (1992). Identification and stimulation by serotonin of intrinsic sensory neurons of the submucosal plexus of the guinea pig gut: activity-induced expression of Fos immunoreactivity. Journal of Neuroscience 12, 235-249.

Li, Y. \& Owyang, C. (1993). Vagal afferent pathway mediates physiological action of cholecystokinin on pancreatic enzyme secretion. Journal of Clinical Investigation 92, 418-424.

Li, Y. \& Owyang, C. (1994). Endogenous cholecystokinin stimulates pancreatic enzyme secretion via vagal afferent pathway in rats. Gastroenterology 107, 525-531.

Mei, N. (1983). Sensory structures in viscera. In Progress in Sensory Physiology, vol. 4, pp. 2-42 [H. Autrum, D. Ottoson, E. R. Perl, R. F. Schmidt, H. Shimazu and W. D. Willis, editors]. New York: Springer Verlag.

Menetrey, D. \& Basbaum, A. I. (1987). Spinal and trigeminal projections to the nucleus of the solitary tract: a possible substrate for somatovisceral and viscerovisceral reflex activation. Journal of Comparative Neurology 255, 439-450.

Menetrey, D., Gannon, A., Levine, J. D. \& Basbaum, A. I. (1989). Expression of c-fos protein in interneurons and projection neurons of the rat spinal cord in response to noxious somatic, articular, and visceral stimulation. Journal of Comparative Neurology 285, 177-195.

Mesulam, M. M. (1982). Principles of horseradish peroxide neurochemistry and their applications for tracing neural pathways - axonal transport, enzyme histochemistry, and light microscopy analysis. In Tracing Neural Connections with Horseradish Peroxidase, pp. 1-151 [M. M. Mesulam, editor]. Chichester: Wiley.

Moran, T. H. \& McHugh, P. R. (1992). Vagal receptor transport. In Neuroanatomy and Physiology of Abdominal Vagal Afferents, pp. 157-177 [S. Ritter, R. C. Ritter and C. D. Barnes, editors]. Boca Raton: CRC.

Perdue, M. H. \& McKay, D. M. (1994). Integrative immunophysiology in the intestinal mucosa. American Journal of Physiology 267, G151-G165.

Pothoulakis, C., Castagliuolo, I., La Mont, T., Jaffer, A., O'Keane, J. C., Snider, R. M. \& Leeman, S. E. (1994). CP-96,345, a substance $P$ antagonist, inhibits rat intestinal responses to Clostridium difficile toxin A but not cholera toxin. Proceedings of the National Academy of Sciences, USA 91, 947-951.

Raybould, H. \& Taché, Y. (1988). Cholecystokinin inhibits gastric motility and emptying via a capsaicin sensitive vagal afferent pathway in rats. American Journal of Physiology 255, G242.

Renehan, W. E., Zhang, X., Beierwaltes, W. H. \& Fogel, R. (1995). Neurons in the dorsal motor nucleus of the vagus may integrate vagal and spinal information from the GI tract. American Journal of Physiology 268, G780-G790. 
Rogers, R. C. \& Hermann, G. E. (1992). Central regulation of brainstem gastric vago-vagal control circuits. In Neuroanatomy and Physiology of Abdominal Vagal Afferents, pp. 100-156 [S. Ritter, R. C. Ritter and C. D. Barnes, editors]. Boca Raton: CRC.

Rogers, R. C. \& McCann, M. J. (1993). Intramedullary connections of the gastric region in the solitary nucleus: a biocytin histochemical tracing study in the rat. Journal of the Autonomic Nervous System 42, 119-130.

Rogers, R., McTigue, D. \& Hermann, G. (1995). Vagovagal reflex control of digestion: afferent modulation by neural and endoneurocrine factors. American Journal of Physiology 268, G1-G10.

Sengupta, J. N. \& Gebhart, G. F. (1994). Gastrointestinal afferent fibers and sensation. In Physiology of the Gastrointestinal Tract, 3rd ed., pp. 483-519 [L. R. Johnson, D. H. Alpers, J. Christensen, E. D. Jacobson and J. Walsh, editors]. New York: Raven Press.

Stead, R. H., Tomioka, M., Quinonez, G., Simon, G. T., Felten, S. Y. \& Bienenstock, J. (1987). Intestinal mucosal mast cells in normal and nematode-infected rat intestines are in intimate contact with peptidergic nerves. Proceedings of the National Academy of Sciences, USA 84, 2975-2979.

Taylor, D. C. M., Pierau, F.-K. \& Schmid, H. (1983). The use of fluorescent tracers in the peripheral sensory nervous system. Journal of Neuroscience Methods 8, 211-224.

Wan, X. S. T., Trojanowski, J. Q. \& Gonatas, J. O. (1982). Cholera toxin and wheat germ agglutinin conjugates as neuroanatomical probes: their uptake and clearance, transganglionic, and retrograde transport and sensitivity. Brain Research 243, 215-224.

Yoneda, M. \& Taché, Y. (1995). Serotonin enhances gastric acid response to TRH analog in the dorsal vagal complex through 5HT2 receptors in rats. American Journal of Physiology 269, R1-R6. 